\title{
Document Human Rights Film Festival 2017
}

\section{Alexandra-Maria Colta}

The autumn season in Glasgow is a celebration of alternative cinema at its wildest, most creative and socially engaged through a variety of film festivals, from Take One Action and Scottish Queer International Film Festival (SQIFF) to Scottish Mental Health Arts and Film Festival (SMHAFF) and Africa in Motion. Document Human Rights Film Festival (henceforth called "Document") is the city's longest-running event dedicated to human rights documentaries. In October 2017 it celebrated its fifteenth edition, filling the cinemas and conference rooms of the Centre for Contemporary Arts (CCA), the festival's main hub. To review this festival and what it represents, one needs to consider the context of film festivals in the city that foster an alternative discourse around films and media. This review approaches Document 2017 as a form of storytelling that contributes to this alternative discourse through its programme, or argument. By adopting the term "argument" in the context of film festivals, Laura Marks offers an interesting perspective on programming, seen as a more objective practice focused on showcasing works under a general theme, versus "curating" as a more subjective practice, driven by concept, which should (and often does) propose a thesis, supported by clearly defined criteria and inviting "agreement, qualification, or dissent" (Marks 43). This review explores the subjective process of curating and the creative assemblage of films and off-screen events at Document 2017, and how it produced an argument about human rights and cinema more broadly. Focusing on the strands of women's rights, censorship and ethics, I engage with the tension between ideas of the festival as a cultural right or as a privilege.

Document 2017 offered a condensed three-day programme of 44 feature and short documentaries, four panel discussions, a filmmaking workshop and a critical forum for filmmakers and activists. Outwith the festival dates and the main venue, Document held local screenings in community-led locations around the city, as well as in galleries such as Glasgow's Pipe Factory, which hosted a retrospective of Vietnamese director Trinh T. Minhha, Talbot Rice in Edinburgh, which paired films about migration with the exhibition Vertigo Sea, and universities, with the University of Glasgow hosting the screening of the Battle of Chile trilogy (La batalla de Chile: La lucha de un pueblo sin armas, Patricio Guzmán, 197579). The screening was interrupted at predetermined moments throughout each part to facilitate discussion and interpretation around formal qualities such as sound or editing and on the political and historical context.

As a researcher embedded in the organisation and part of the team of four for the selection panel, this review is written with the additional knowledge of how the programme was constructed and framed. The festival's main thesis emerged organically during the programming process, when many of the films viewed for selection offered different perspectives on power, the notion of truth and ethics within societies globally. The festival's 
programme challenged freedom of expression and its limitations by showing contentious stories alongside discussions that interrogate their validity. The development of Document and its annual output are part of this curatorial freedom and power to create new meanings around film, and the privilege to debate without censorship.

Document's identity is defined by its history, programme and partnerships with the international Human Rights Film Network (HRFN) and the various thematic festivals in Glasgow. Document's human rights approach started as a drive to represent asylum seekers and refugees on screen in a manner that counteracts mainstream media discourses centred on fear and hatred. The festival's programme developed to include a broad range of issues and documentary forms while avoiding a fixed, determined definition of human rights. In conforming to its history but also its membership of the HRFN, a network of forty human rights film festivals around the world, Document's approach to human rights is guided by the principles of universality, on the basis of being human and deserving of a decent life. The festival in 2017 reiterated this legacy, but focused on showing marginalised, unheard voices on a few, select topics, rather than covering a broad range of themes and issues. The main strands revolved around the struggles for gender equality, self-determination and speaking truth to power.

"Jin, Jiyan, Azadi: Gender Equality in Kurdish Society" (Jin, Jiyan, Azadi translates into "Women, Life, Freedom") presented a collection of films and stories focusing on the roles and feminism of Kurdish women. The festival opened with Gulistan, Land of Roses (Zayne Akyol, 2016) an observational documentary about women guerrilla fighters in the controversial PKK (Kurdistan Workers' Party). Rather than focusing on the fight and resistance to ISIS, the director offers unprecedented access to the women's daily routines, as they train, braid, discuss politics and name their guns. The atrocities of war arise in their testimonies and physical scars, while the film seems to intentionally avoid the loudness and violence of the fight zones. In contrast, Resistance is Life (Apo W. Bazidi, 2017) propels viewers in the middle of a refugee camp on the Turkish-Syrian border as they support Kurdish female fighters, their fight and subsequent victory against ISIS over the city of Kobanî in Syria. Through the perspective of an eight-year-old girl, the film captures refugee life beyond the border, in a state of stasis and anxiety waiting to return to their homeland. Radio Kobanî (Reber Dosky, 2016) offers a portrait of a twenty-year-old woman who sets up a radio station in Kobanî during the liberation fight against ISIS. The radio programme records testimonies of poets, activists and fighters, interweaved with the woman's own story and with often shocking footage of rubble, dismembered bodies and dust.

These three films focus on empowered Kurdish women and their voices within a contested context. From an audience perspective, this programming choice implied the act of "watching others" from a distance and watching their lives unfold on screen from a position of relative privilege (Tascón). Human rights film festivals can challenge detached spectating positions through off-screen events that use films as starting points for activism (Tascón). The panel discussion that brought together the Kurdish films strand offered an opportunity for engagement and practical ways to act. For instance, the speakers went beyond the films to discuss a current movement in the Syrian territory called Rojava, which includes the city of Kobanî. The movement, led by Kurdish leftists who initiated a grassroots radical, egalitarian, multiethnic ministate, is concentrated on direct democracy, where women are at the forefront of political and social decisions. Furthermore, the panel served as a platform for campaigning, where the Scottish Solidarity with Kurdistan organisation offered more information on fundraising for the reconstruction of the city of Kobanî. Ultimately, the 
argument put forward by this strand was that change can come from the most unexpected places, even in the war-torn Middle East. It also showed how the festival's role is not necessarily aimed at defining human rights, but showing how they are connected. For instance, this strand emphasised how the Kurdish "issue" is a struggle for self-determination, gender equality, asylum and protection.

Another key strand of Document 2017 called "Truth and Power: Control Room and Other Stories" focused on censorship and freedom of speech in the era of "fake news". This strand is one of the most apt examples of curation in Marks's understanding of the term, driven by a subjective agenda. In this case, the programmers selected a variety of films that fit their idea, making it appear as a festival within a festival. Document curated several documentaries that were selected for the $11^{\text {th }}$ Beijing Independent Film Festival (BIFF) in 2014, which was cancelled by the Chinese authorities, to address the notion of censorship and the role of government in imposing narratives on filmmakers and on the populace. The festival, organised by a local film fund, had been repeatedly under pressure from the Chinese government until it was forced to shut down just one day before the opening gala. This action sparked criticism and support globally and other platforms offered to host those films, including the New York screening of 28 films that were intended for the BIFF (Lattanzio). Document screened two films, I Want to Be a People's Representative (Wo yao dang renmin daibiao, Jia Zhitan, 2013) and The VaChina Monologues (Popo Fan, 2013). The former follows a man from a Chinese village using a camera to trace the bureaucratic obstacles he faces when he wants to run as a delegate for the National People's Congress. The VaChina Monologues focuses on American feminist playwright Eve Ensler's The Vagina Monologues, as it controversially circulated around China over ten years. These two films were accompanied by the documentary A Filmless Festival (Meiyou dianying de dianyingjie, Wang Wo, 2015) following the sequence of events during BIFF's cancellation. It is presented through various professional and nonprofessional cameras and offers first-hand experiences of the people involved in the festival and festivalgoers as they deal with oppressive, sometimes violent reactions from the authorities. Offering a platform for otherwise blacklisted films in the country they were first meant to be screened illustrates Document's aim to be "a platform, an amplifier even, for points of view struggling to find voice", as the 2017 brochure suggests. The films' topic and controversy overruled other criteria that usually inform programming such as exclusivity or newness. In this case, the films from the cancelled BIFF were already four years old, but illustrated the idea of a festival as a cultural right, as a vehicle for freedom of expression and access to culture. The same strand also included Brian Springer's documentary SPIN (1995), composed of behind-the-scenes footage of politicians and newscasters in the 1990s. Control Room (Jehane Noujaim, 2004), the titular film of the panel, provides insight into Al Jazeera's presentation of the second Iraq War to their worldwide audience.

A welcome addition to the strand was a comedy, an unexpected presence in the context of human rights film festivals. Following the aesthetic of a mockumentary, Kim Jongil's Comedy Club (Det røde kapel, Mads Brügger, 2009) was introduced as a late-night cult classic in collaboration with Matchbox Cineclub. The film focuses on the director and two Danish-South Korean comedians as they travel to North Korea to put on a play for a select audience and, surprisingly, overcome forms of censorship in one of the world's most notorious regimes. From a programming perspective, a human rights comedy is a rare sight, which determined its selection for its role in subverting expectations about the form and ethics of documentary filmmaking. As the film tests the limits of the protagonists and the 
oppressive system, it also challenges its viewers by stimulating reflection on the irony of laughing at the absurdity and horrors of the North Korean regime.

This mockumentary overlapped with another connected panel under the same strand, focusing on the ethical implications of filmmaking and the credibility and integrity of directors in relation to their subjects. This concept informed the grouping of films that push the ethical boundaries such as Left on Purpose (Justin Schein and David Mehlman, 2015) about the life of a former activist of the radical anti-war and free-speech yippie movement in 1960s America, a colourful and quirky character dealing with alcoholism and depression. The project takes a dramatic turn when the man reveals he intends to kill himself as his final political act and he wants it to be on camera. The film raises more questions than answers about the right to take one's life and the role of the camera as a potential incentive for this gesture. The panel discussion on the "Ethics of the Documentary Filmmaker" challenged ways of representing vulnerable or controversial people and debated self-censorship as a tool for documentary filmmakers. Andrea Luka Zimmerman joined the panel and brought her experience of making Erase and Forget (2017), a documentary that held its Scottish premiere at Document. Zimmerman's film combines impressive visual material to portray "Bo" Gritz, a contentious figure and one of America's most decorated Vietnam veterans, allegedly the inspiration behind Rambo. The discussion focused on the ethical issues of production rather than the content itself, a common thread across documentaries and strands, as it is part of the process of validating filmmakers before evaluating their arguments. The audience attended this panel in large numbers, which suggests festivals are also platforms where spectators can question filmmakers' ways of looking and representing subjects on screen, and can validate or disrupt these discourses.

Another film in this panel that challenged detached spectatorship at human rights film festivals was Stranger in Paradise (Guido Hendrikx, 2016), a hybrid documentary that combines acting and artificially constructed situations with real migrants. An actor (Valentijn Dhaenens) takes different approaches to a class full of migrants recently arrived in Europe. He first confronts them, then he praises them for their courage, before explaining the official procedures for obtaining a residence permit in the Netherlands. Beyond the unsettling feeling arising from the performance of right-wing xenophobic discourse, and playing with vulnerable people for filmmaking's sake, the documentary also addresses film festivals as the ultimate platforms for the spectacle and consumption of images of suffering. This documentary, framed within the ethics panel, within the strand that celebrates freedom of expression as a right and a privilege - the festival within a festival, has captured the essence of the whole programme.

Document 2017 offers a subjective narrative of human rights issues and cinema that, under the "freedom of expression" banner, invites marginalised, sometimes contentious voices, to address past and current situations. As the opening statement from the brochure indicates, "We look to those speaking truth to power and those with the power to manage what we hear and see", acknowledging, at the same time, that festivals themselves also hold tremendous power over what and how we watch films. This perspective invites reflection on this power: is it taken for granted, a privilege we are becoming more accustomed to in a growing festival market that creates further distance between us as watchers of others' problems, or is it an opportunity to interrogate this privilege and use this knowledge differently? 


\section{References}

A Filmless Festival [Meiyou dianying de dianyingjie]. Directed by Wang Wo, Wang Wo Studios, 2015.

Battle of Chile [La batalla de Chile: La lucha de un pueblo sin armas]. Directed by Patricio Guzmán, Equipe Tercer Ano and Instituto Cubano del Arte e Industrias Cinematográficos (ICAIC), 1975-79.

Control Room. Directed by Jehane Noujaim, Noujaim Films, 2004.

Ensler, Eve. The Vagina Monologues. Villard Books, 2007.

Erase and Forget. Directed by Andrea Luka Zimmerman, Fugitive Images, Bright Wire Films, 2017.

Gulîstan, Land of Roses. Directed by Zaynê Akyol, Mitosfilm, National Film Board of Canada (NFB), Peripheria Productions, 2016.

I Want to Be a People's Representative [Wo yao dang renmin daibiao]. Directed by Jia Zhitan, 2013.

Kim Jong-il's Comedy Club [Det røde kapel]. Directed by Mads Brügger, Danmarks Radio (DR), Film i Väst, Zentropa Productions, 2009.

Lattanzio, Ryan. "New York Rescues Beijing Independent Film Festival.” IndieWire, 14 July 2015, www.indiewire.com/2015/07/new-york-rescues-beijing-independent-film-festival-186059/.

Left on Purpose. Directed by Justin Schein and David Mehlman, Shadowbox Films Inc., 2015.

Marks, Laura U. "The Ethical Presenter: Or How to Have Good Arguments over Dinner." The Moving Image: The Journal of the Association of Moving Image Archivists, vol. 4, no. 1, 2004, pp. 34-47.

Radio Kobanî. Directed by Reber Dosky, Dieptescherpte, 2016.

Resistance is Life. Directed by Apo Bazidi, Burn a Light Productions, 2017.

SPIN. Directed by Brian Springer, 1995.

Stranger in Paradise. Directed by Guido Hendrikx, Zeppers Film \& TV, 2016.

Tascón, Sonia M. Human Rights Film Festivals: Activism in Context. Palgrave Macmillan, 2015.

The VaChina Monologues. Directed by Popo Fan, The Beaver Club, Queer Comrades, 2013. 


\section{Suggested Citation}

Colta, Alexandra-Maria. "Document Human Rights Film Festival 2017." Festival Report. Alphaville: Journal of Film and Screen Media, no. 14, Winter 2017, pp. 239-244. www.alphavillejournal.com/Issue14/ReportColta.pdf. ISSN: 2009-4078.

Alexandra-Maria Colta is a $\mathrm{PhD}$ student at the University of Glasgow in partnership with the University of St Andrews and Document Human Rights Film Festival, an ARCS-funded collaborative framework for the interdisciplinary study of human rights film festivals. Alexandra studied media and cultural studies at the Centre for British Studies at Humboldt University, Berlin and worked in film production and promotion in Romania and the UK. 